\title{
Non-Cognitive Skills: How Much Do They Matter for Earnings in Canada?
}

\author{
Dawson McLean \\ Employment and Social Development Canada \\ Mohsen Bouaissa \\ Employment and Social Development Canada \\ Bruno Rainville \\ Employment and Social Development Canada \\ Ludovic Auger \\ Employment and Social Development Canada
}

Evidence from different countries suggests that non-cognitive skills play an important role in wage determination and overall social outcomes, but studies for Canada are scarce. We contribute to filling this gap by estimating wage regressions with the Big Five traits using the Longitudinal and International Study of Adults. Our results indicate that conscientiousness is positively associated with wages, while agreeableness, extraversion, and neuroticism are associated with negative returns, with higher magnitudes on agreeableness and conscientiousness for females. Cognitive ability has the highest estimated wage return so, while significant, non-cognitive skills do not seem to be the most important wage determinant.

Keywords: Labour Market, Returns to Skills, Non-Cognitive Skill, Cognitive Skill, Wage Regressions, Personality Traits, Five-Factor Model

\section{INTRODUCTION}

Since the ground-breaking work of Jacob Mincer in the 1970s, economists and policy-makers have been interested in empirically examining the determinants of wages for labour market participants. The focus for much of this literature remained on the effect of experience, education and cognitive ability on wages and it was only with a series of papers by Heckman and co-authors in the 2000's that this line of thinking expanded to include the effect of social and emotional skills. While there lacks one agreed-upon strategy to measure these skills in the relatively small literature, a positive relationship between wages and non-cognitive skills is generally understood to exist. The intent of this study is to further add to the understanding of how non-cognitive skills affect wage returns in the labour market by using the Big Five personality traits and an underutilised but powerful Canadian survey of working adults. This paper will consist of first a review of existing literature, an overview of the survey and our derived measures of 
cognitive and non-cognitive skills, then a presentation of the models and estimation strategy followed by a discussion of the results.

\section{REVIEW OF RELEVANT LITERATURE}

Gary Becker set the stage for the present analysis in the 1960s by being among the first to formally describe the process of engaging in education as an individual investment decision, with pay-offs in the form of higher future wages. This ultimately motivated Jacob Mincer ten years later to develop the famous Mincer Equation, which attributed differences in cross-sectional wages to differentials in schooling and experience.

In this framework, cognitive ability is seen as an endowment factor which differentiates marginal productivity, helping to partially explain wage differentials. Cawley, Heckman and Vytlacil (2001) estimate the magnitude of this effect using the NLSY survey, showing that a one standard deviation increase in innate thinking ability is associated with between $10 \%$ and $15 \%$ higher wages. Both Cawley, Heckman and Vytlacil (2001) and Cunha, Heckman, Lochner and Masterov (2006) also suggest that, rather than being a fixed endowment, cognitive ability can evolve over a lifetime, dynamically affecting wages both through increased schooling and higher productivity. More recently, Hanushek, Schwerdt, Wiederhold, and Woessmann (2015) used data from the 2012 Programme for International Assessment of Adult Competencies (PIAAC) survey to examine the relationship between numeracy and literacy abilities and wages. They find evidence of a positive relationship, however concede that the selection process of high-skilled individuals into higher levels of schooling may confound the true effect. Cawley, Heckman and Vytlacil (2001) find that cognitive ability, while statistically a significant predictor of income, explains only a small fraction of the variation in income, suggesting that other, unobserved factors may also play a key role in determining economic success. This then opens the discussion on the ability of other unobserved traits to affect economic outcomes of an individual. Mischel (1973) argued that personality traits are one fundamental factor in helping determine how an individual responds to stimulus in their environment in a consistent way. Thus we could reasonably expect personality traits to form a part of an individual's stock of human capital and to be associated with labour market outcomes.

Non-cognitive skills are notoriously difficult to measure, given the lack of consensus in the literature on their definition and which proxies are most appropriate. One strategy that has received widespread acceptance involves quantifying non-cognitive skills using the Five Factor Model (Goldberg, 1971; Costa and McCrae, 1985). The Five Factor model posits the existence of five distinct but not necessarily orthogonal personality characteristics, the Big Five personality traits. These characteristics, Openness to Experience, Conscientiousness, Extraversion, Agreeableness and Neuroticism, are traits that are theorised to help determine a personality that is consistent across time and situation. The Big Five are derived from well-established definitions in the psychology literature dating back to the seminal lexical work by Allport and Odbert (1936), and have seen applications in numerous economic studies attempting to find links between personality and learning, work, romantic and social outcomes. The traits are characterised as relative rigid over the life cycle, particularly by the age of 25-30 (Cobb-Clark and Schurer, 2011). ${ }^{1}$

Each of the Big Five dimensions in turn are made up of several smaller personality facets, which are typically more easily measured using survey questions. John and Srivastava (1999), McCrae and John (1992) and others outline the history of the Five Factor Model and in particular highlight which facets are associated with which personality dimensions. Openness to Experience, for example, is associated with concepts at the intersection of intelligence and ingenuity such as imagination, being artistic and thoughtfulness. Neuroticism, on the other hand, is associated with facets such as anxiety, selfconsciousness, and vulnerability. Facets for the other three dimensions can be found in Appendix A.

While the Five Factor Model has its criticisms, its robustness, relative ease of interpretation and applicability to survey questionnaires have made it an attractive option for economists interested in studying personality. Numerous papers have attempted to tie these personality traits to economic outcomes, including two early papers by Barrick and Mount (1991) and Tett, Jackson and Rothstein (1991) who review work linking these characteristics to the labour market. Barrick et al. in particular find 
that conscientiousness has a strong positive correlation with job performance for all occupational groups, while the impact of the other four traits are differentiated by occupation type. Judge, Higgins, Thoresen, Barrick and Murray (1999) use longitudinal data to find that conscientiousness and extraversion are positively related to various metrics of career success, while neuroticism and agreeableness are negatively correlated. Nyhus and Pons (2005), Mueller and Plug (2006), and Heineck and Anger (2010) unanimously find that conscientiousness is the most positively associated with and predictive of higher earnings, while agreeableness and neuroticism may be associated with negative returns. Nyhus and Pons find extraversion to have negative returns, while Mueller and Plug find this is true only for females. Mueller and Plug are also the only to find a positive estimated return to openness to experience. Almlund (2011) affirm these main findings, suggesting that conscientiousness is the best overall predictor of job performance, though this correlation decreases with increased job complexity. Openness to experience and extraversion are found to be positively associated with job performance but only indirectly through education. A positive relationship between extraversion and education is not a consistent finding, however, as Goldberg (1998) and van Eijck and de Graaf (2004) find a slight negative relationship between educational attainment and neuroticism, extraversion and agreeableness.

Of course, using the Big Five dimensions is also not the only identification strategy used in the literature. In a highly influential paper, Heckman and Rubinstein (2001) use enrolment in a General Education Development (GED) program as a measure of non-cognitive skill and find that differences in social skills between GED and high school graduates explain a large proportion of the wage differential between the two groups. Heckman, Stixrud and Urzua (2006) used the Rotter Locus of Control Scale and the Rosenberg Self-Esteem Scale derived from the 1979 National Longitudinal Survey of Youth (NLSY) as their preferred indicators, again finding evidence that non-cognitive skills strongly influence schooling decisions and wages. In another influential paper, Lindqvist and Vestman (2011) use an administrative dataset of Swedish military enlistees to derive a measure of personality as assessed by interviews with professional psychologists. Their results show that individuals who struggle with low earnings and unemployment are systematically characterised by low non-cognitive skill scores. Borghans, ter Weel and Weinberg (2014) use data from the NLSY to determine if differences in non-cognitive skills are able to predict wage differentials between minority and gender groups. In a related line of thinking, they look at whether returns to what they term 'people skills' have increased or decreased with time. They find that, between the 1970s and 1990s, non-cognitive skills have become increasingly important determinants of wages, which they attribute to an increased substitution of technology to perform tasks. This line of reasoning is affirmed by Weinberger (2014), Deming (2017) and Edin, Fredriksson, Nybom and Öckert (2017), who each find evidence of returns to non-cognitive skills increasing over time, and their growing importance to working in high-paying managerial occupations.

While the existing literature provides evidence for a wide array of OECD countries, to our knowledge there is only one paper that examines the data specifically for Canada. Green and Riddell (2003) use Canadian male respondents from the 1994 International Adult Literacy Survey (IALS) to conclude that an individual's cognitive abilities are primarily established during formal schooling. In line with the literature, they also suggest that cognitive and non-cognitive skills affect earnings both independently and through an interplay between them. Our work in this paper thus builds upon the foundation established by Heckman, Green and Riddel and others that already exists in the literature. We contribute to the knowledge gap in the literature first by directly measuring both cognitive and noncognitive skills and focussing on how cognitive and non-cognitive skills are independently rewarded in the Canadian labour market. To our knowledge, we are also among the first to use the Longitudinal International Survey of Adults (LISA) to analyse this question, which will allow us to offer further empirical evidence to the literature from an under-studied OECD country. The advantages of using the LISA survey are two-fold. First, it offers some of the most recent data available for studying earnings and wage data, and will also allow for the robust examination of heterogeneity in cognitive and non-cognitive skill returns across a wide spectrum of Canadian workers. ${ }^{1}$ 


\section{DATA DESCRIPTION}

The estimations in this paper rely on data from the Longitudinal International Survey of Adults (LISA). LISA is a biennial survey administered by Statistics Canada, collecting information on individual's education, family and labour characteristics. Three waves of data exist, the most recent having become available in late 2018, though we focus exclusively on the first two waves only. The survey was administered to a random sample of Canadians by either computer or paper in their official language of choice. ${ }^{2}$ A portion of the wave 1 (2012) LISA respondents were invited to complete the LISA survey after having first completed the 2012 Programme for International Assessment of Adult Competencies (PIAAC) survey. PIAAC contains a series of questions intended to measure numeracy, literacy and problem-solving abilities, which we ultimately use to inform our measure of cognitive ability. The second wave of LISA contains a series of responses to 15 questions assessing an individual's personality traits with respect to the Big Five framework. Each personality dimension is associated with three distinct questions in the survey, and these three responses are what inform our five measures of noncognitive skills. ${ }^{3}$ LISA also allows us to observe a wide array of personal characteristics such as age, marital status, self-reported years of education and experience, and occupational classification and characteristics derived from National Occupational Classification (NOC) codes. Measures of individual earnings and income originate from an administrative data file containing T1 Family File and T4 records, linked to LISA responses by Statistics Canada. Pension and immigration flags are supplied by linked records from the Pension Plan in Canada Survey and the Longitudinal Immigration Database.

\section{Sample Selection}

To be included in the sample, a respondent's cognitive and non-cognitive skill must be observed. Hence, they must have responded to both waves of LISA and also the PIAAC questions. ${ }^{4}$ This corresponds to 6,162 individuals. The final estimation sample consists of slightly less than $60 \%$ of all joint PIAAC and LISA respondents. To be included in the sample, respondents must have been working full time, not have been self-employed or have an unknown employment status, have a known occupation, answered all the Big Five questions, and have reported non-zero employment income. The final estimation sample contains 3,571 observations, or 13,859,618 after the application of frequency weights. Sample size at each stage of the selection process is detailed in Table 1.

TABLE 1

SAMPLE SELECTION STEPS

\begin{tabular}{lccc}
\hline \multicolumn{1}{c}{ Selection Step } & Observations & Weighted obs. & Weighted fraction (\%) \\
\hline PIAAC participants & 6,162 & $23,351,666$ & 100.00 \\
Working full time & 4,382 & $16,838,430$ & 72.11 \\
Employees & 3,688 & $14,395,946$ & 61.65 \\
Known occupation & 3,679 & $14,314,970$ & 61.3 \\
Answered 'Big Five' section & 3,649 & $14,195,046$ & 60.79 \\
Reported employment income & 3,571 & $13,859,618$ & 59.35 \\
\hline
\end{tabular}

Source: LISA (2012-2014): Authors' calculations.

Frequency weights are calculated by Statistics Canada to correct for the probability of inclusion in the sample. Four different weights are available, the ones used here are the longitudinal weights applied to the subsample of Wave 1 PIAAC respondents. Weighted summary statistics of some of the continuous variables of interest are presented in Table 2. 
TABLE 2

WEIGHTED MEANS OF SELECTED VARIABLES

\begin{tabular}{lccc}
\hline \multicolumn{1}{c}{ Variable } & All Sample & Males & Females \\
\hline Annual income (\$) & $37,040.60$ & $44,750.59$ & $30,596.17$ \\
Log wage & 10.52 & 10.71 & 10.33 \\
Years of education & 14.74 & 14.65 & 14.83 \\
Years of experience & 15.96 & 17.43 & 14.48 \\
Age & 40.64 & 40.71 & 40.57 \\
Single & 0.62 & 0.62 & 0.63 \\
Immigrant & 0.20 & 0.20 & 0.20 \\
Degree outside Canada & 0.11 & 0.11 & 0.11 \\
Union & 0.33 & 0.32 & 0.34 \\
\hline Sourc: LISA (2012-2014): Authors
\end{tabular}

Source: LISA (2012-2014): Authors' calculations.

These averages compare reasonably well to Canada-wide estimates derived by Statistics Canada. For example, average annual income in 2012 (in 2012 dollars) for all Canadian workers both full-time and part-time is reported at $\$ 41,222$, slightly higher than in our sample, and is also estimated as higher for males than females, which also reflects the realities of the Canadian labour market (CANSIM Table 1110-0240-01). The average age of the Canadian population, derived from the 2016 census, is estimated at 41 years, lining up well with our estimates. ${ }^{5}$

Weighted means of selected educational and National Occupational Classification (NOC)-derived variables are presented in Table 3. Education Level represents the highest level of academic credential the individual has achieved at the time of the survey, and is derived directly from responses to the LISA questionnaire. Task Type and Skill Level are derived from the NOC code of the individual's occupation, as recorded in the LISA survey, following the task classifications defined by Autor, Levy, and Murnane (2003). Skill levels are defined in descending order; that is, Level C and D correspond to the lowest skill levels, requiring only on-the-job training or a secondary school education. Level B requires college or apprenticeship training, while Level A is usually associated with a university post-secondary education. Table 3 suggests that workers are split relatively evenly between Routine and Non-Routine-classified occupations while $61 \%$ of workers are employed in Manual or Interactive occupations. The remaining $39 \%$ find themselves in Cognitive or Analytic-focussed jobs. Among each of these categories, the malefemale split is relatively even, with the exception of Routine Manual and Non-Routine Manual, which are dominated by Males, and Non-Routine Interactive, where the opposite is true. Additionally, 37\% of individuals find themselves in the lowest skill level occupations, while $27 \%$ of Canadians in the sample work in high-skill level jobs. $63 \%$ are estimated to work in skilled occupations requiring at least some post-secondary education, which is consistent with the finding that $64 \%$ of individuals in the sample have attained some form of post-secondary educational credential. 
TABLE 3

WEIGHTED MEANS OF EDUCATION AND NOC-DERIVED VARIABLES

\begin{tabular}{lccc}
\hline \multicolumn{1}{c}{ Variable } & All Sample & $\begin{array}{c}\text { Males (proportion of } \\
\text { category) }\end{array}$ & $\begin{array}{c}\text { Females (proportion } \\
\text { of category) }\end{array}$ \\
\hline $\begin{array}{l}\text { Task Type } \\
\text { Manual Routine }\end{array}$ & 0.26 & 0.61 & 0.39 \\
Non-Routine Interactive & 0.26 & 0.32 & 0.68 \\
Non-Routine Manual & 0.09 & 0.74 & 0.26 \\
Routine Cognitive & 0.25 & 0.47 & 0.53 \\
Non-Routine Analytic & 0.14 & 0.53 & 0.47 \\
$\quad$ Skill Level & & & 0.54 \\
Level C/D & 0.37 & 0.46 & 0.43 \\
Level B & 0.36 & 0.57 & 0.58 \\
Level A & 0.2 & 0.42 & 0.39 \\
Management & 0.07 & 0.61 & 0.5 \\
$\quad$ Education Level & & & 0.47 \\
Less than HS & 0.11 & 0.5 & 0.48 \\
HS Diploma & 0.25 & 0.53 & 0.55 \\
Post-Secondary Below & & & 1923 \\
BA & 0.37 & 0.52 & $6,862,534$ \\
BA and Higher & 0.27 & 0.45 & \\
\hline$\quad$ Observations & 3571 & 1648 & \\
$\quad$ Weighted Obs. & $13,859,618$ & $6,967,084$ & \\
\hline
\end{tabular}

${ }^{\dagger}$ Education category 'No Education / Unknown' omitted due to small sample size

Source: LISA (2012-2014): Authors' calculations.

\section{Cognitive Abilities}

The cognitive ability scores to be used in the following estimations are derived from responses to the PIAAC literacy and numeracy questions. ${ }^{6}$ To reduce the response burden on PIAAC respondents, an individual responds to a sample of the total universe of questions where the difficulty of the questions presented to the respondent adapts to their ability. An Information Response Theory (IRT) model is then fitted to the responses, which allows for the prediction of 10 plausible values (PV) of an individual's latent ability based on its estimated posterior distribution. We derive literacy and numeracy scores for each individual as the average of their 10 plausible values. Further calculations, including regressions, involving average literacy and numeracy scores must account for the increased variance introduced by the plausible values, so we follow von Davier, Gonzalez and Mislevy (2009) to compute correct standard errors. $^{7}$

TABLE 4

MEAN AND VARIANCE OF PIAAC COGNITIVE ABILITY SCORES

\begin{tabular}{lccccc}
\hline & & \multicolumn{2}{c}{ Literacy } & \multicolumn{2}{c}{ Numeracy } \\
\cline { 2 - 5 } & Observations & Average & s.e. & Average & s.e. \\
\hline Full Sample & 3571 & 281.53 & $(1.1)$ & 273.32 & $(1.21)$ \\
Males & 1648 & 282.27 & $(1.67)$ & 279.73 & $(1.83)$ \\
Females & 1923 & 280.77 & $(1.54)$ & 266.84 & $(1.68)$ \\
\hline
\end{tabular}

Standard errors in parentheses corrected for plausible values

Source: LISA (2012-2014): Authors' calculations. 
Between the two, average literacy scores appear to be slightly higher than numeracy scores, though numeracy is the only category to exhibit a statistically significant difference in average scores between males and females. ${ }^{8}$ We estimate the coefficient of correlation between numeracy and literacy scores to be $\hat{\rho}=0.91$, suggesting that, independently, each indicator does not add a great deal of additional information to our measure of latent cognitive ability.

We generate our measure of cognitive ability using a two-step procedure. First, we estimate a factor model using the plausible value scores in order to model latent cognitive ability. Factor analysis assumes that literacy and numeracy scores are jointly determined by a set $n$ of unobserved factors $F$. In our case, we presume the existence of one factor, cognitive ability. Estimation of the factor model allows us to predict cognitive ability scores as standardized, normally-distributed, mean zero unit variance indices.

We further investigate the behaviour of the cognitive ability scores by estimating kernel densities by education level. Figure 1 demonstrates that with higher education, we can expect the distribution of cognitive ability to shift to the right, suggesting that, unsurprisingly, there is a relationship between cognitive ability and education level.

\section{Non-cognitive Abilities}

Respondents to the second wave of the LISA survey answered 15 questions, three per characteristic, related to the Big Five personality characteristics framework. Each of these questions asked respondents to rate themselves on a Likert-type 1 - 7 scale where 1 indicates that the question "does not apply to me at all" and 7 indicates that the question "applies to me perfectly." Like with the cognitive ability indicator, factor analysis can also be applied to the responses of these questions in order to estimate the latent noncognitive skills that interest us. However, as Kolenikov (2004) points out, factor analysis involves modelling responses to the individual questions as continuously jointly normally distributed. This assumption is tenable in the case of continuous literacy and numeracy scores, but does not hold with discrete responses to personality questions. If the variables are not in fact continuous, the distributional assumptions behind the correlation estimation are violated, yielding dubious factor analysis estimates. Correct treatment of this discrete nature involves estimation of the polychoric correlation coefficient. See Kolenikov (2004) for further details of this process. Once consistent polychoric correlation coefficients $\hat{\rho}$ are estimated, the factor variance covariance matrix may be constructed and a usual factor model may be estimated. This process is performed using the Stata package polychoric. This then permits prediction of the latent Big Five personality characteristics as standardized normally-distributed, zero mean unit variance estimates, as above. Kernel density estimates of these factors are shown in Figure 2.

FIGURE 1

\section{KERNEL DENSITIES OF COGNITIVE ABILITY, BY EDUCATIONAL ATTAINMENT}

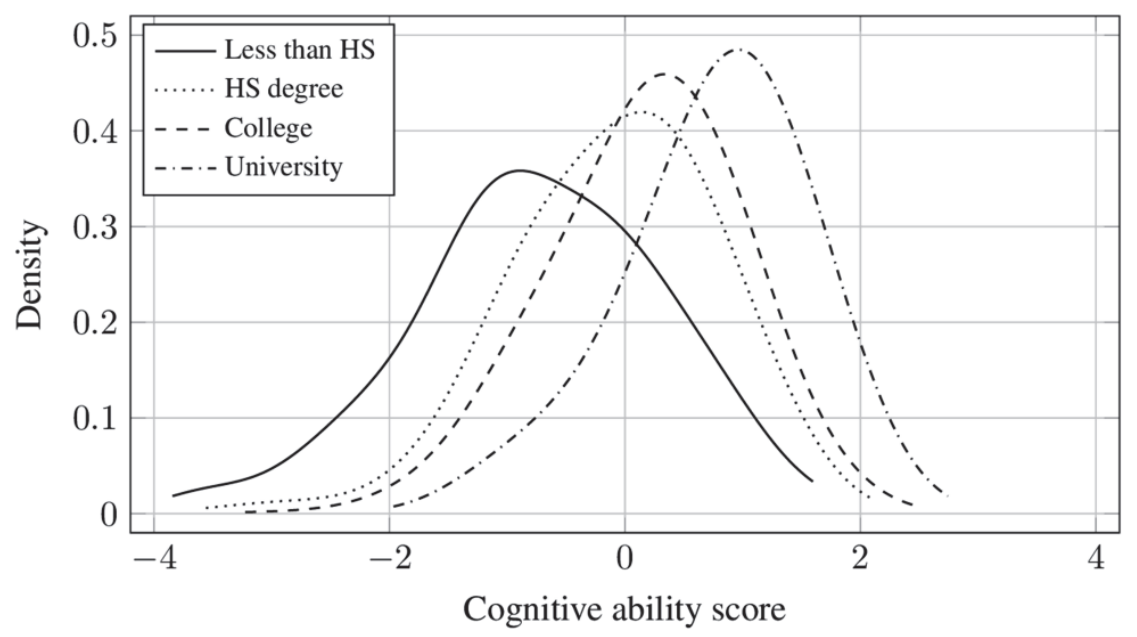

110 American Journal of Management Vol. 19(4) 2019 
FIGURE 2

KERNEL DENSITIES OF BIG FIVE PERSONALITY TRAITS

Openness to Experience

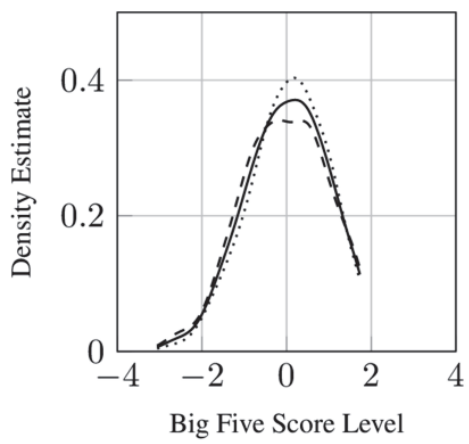

Conscientiousness

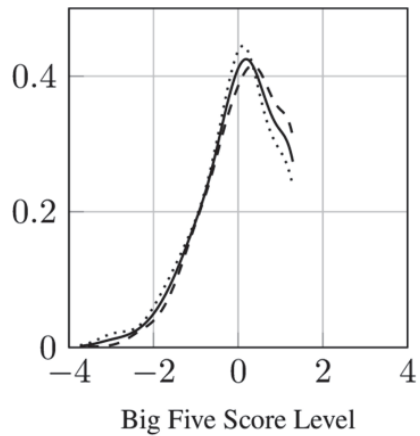

Extraversion

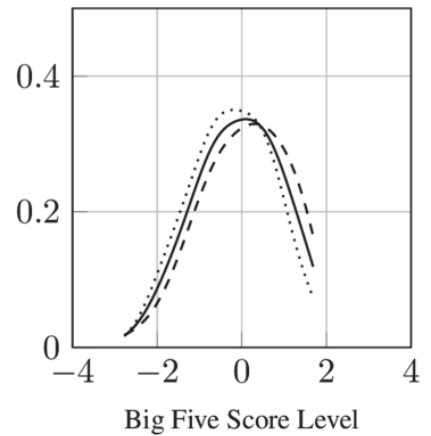

Agreeableness

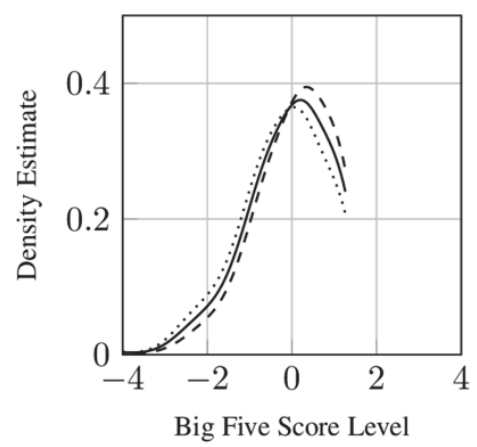

Neuroticism

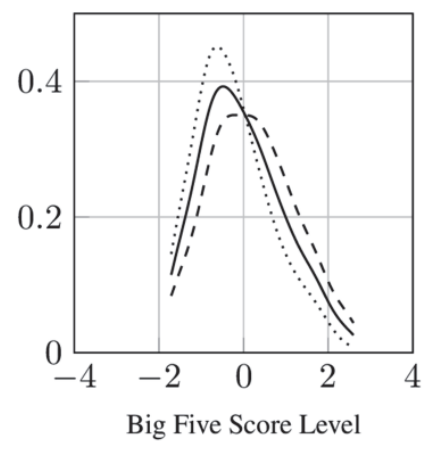

Big Five Score Level

\section{Full sample}

...... Males

- - Females

Of the Big Five characteristics, Openness to Experience and Extraversion appear to have the most normal-shaped distribution, while Conscientiousness, Agreeableness, and Neuroticism each have the greatest differences between males and females, and higher density on the more 'socially desirable' side of the distribution, for example on the side of the distribution associated with being more agreeable. ${ }^{9}$

\section{METHODOLOGY}

Using the standardized cognitive ability and Big Five personality characteristics in addition to the other occupational and individual information derived from LISA, we propose an estimation framework based on human capital theory. We estimate four models, starting with Model 1, a simple Mincer regression of log wages on education and experience:

$\ln \left(\right.$ wage $\left._{i}\right)=\beta_{0}+\beta_{1}$ Educ $_{i}+\beta_{2}$ Exper $_{i}+\beta_{3}$ Exper $_{i}^{2}+\varepsilon_{i}$

Model 2 adds a set of individual characteristics, $\boldsymbol{x}_{i}^{\prime}$, comprising indicator variables recording union membership, marital and immigrant status, whether an individual earned a degree outside the country, province of residence, etc. 
$\ln \left(\right.$ wage $\left._{i}\right)=\beta_{0}+\beta_{1}$ Educ $_{i}+\beta_{2}$ Exper $_{i}+\beta_{3}$ Exper $_{i}^{2}+\boldsymbol{x}_{i}^{\prime} \alpha+\varepsilon_{i}$

Model 3 is identical to the preferred specification of Green and Riddell (2003), where $\operatorname{Cog}_{i}$ is our measure of cognitive abilities and $\boldsymbol{p}_{i}^{\prime}$ is a set of parental education levels. Quadratic terms in education and experience are included in order to capture non-linearities in returns. Likewise, an interaction term between cognitive ability and experience is included to capture heterogeneity in returns to experience for different levels of cognitive ability.

$$
\begin{gathered}
\ln \left(\text { wage }_{i}\right)=\beta_{0}+\beta_{1} \text { Educ }_{i}+\beta_{2} E_{d u c_{i}^{2}}+\beta_{3} \text { Exper }_{i}+\beta_{4} \text { Exper }_{i}^{2}+\beta_{5} \operatorname{Cogn}_{i} \\
+\beta_{6}\left(\operatorname{Cogn}_{i} \times \text { Exper }_{i}\right)+\boldsymbol{p}_{i}^{\prime} \delta+\varepsilon_{i}
\end{gathered}
$$

Our final specification is our preferred specification as it includes measures of both cognitive and the five non-cognitive skills. Existing literature suggests that self-selection into occupation based on skill confounds the true returns to personality traits, so we follow the approach of Borghans et al. (2014), Heineck and Anger (2010), Lindqvist and Vestman (2011) and others in including indicator variables for occupational characteristics to remove this endogeneity. These characteristics are encoded in $\mathbf{z}_{i}^{\prime}$, including the measures listed above, in addition to indicator variables for industry, province, and occupational characteristics. Two specifications of Model 4 will be estimated, including first skill level, then the task content of the occupation in $\boldsymbol{z}_{i}^{\prime}$. This leaves within-industry, within-occupation variation in skills and wages as the identifying variation of the study. Quadratic terms are included for the experience, education and cognitive ability variables to control for non-linearities in their returns. Non-cognitive skills are included in the variable Non_cogn $i, j$, so our interest lies in estimating the set of parameters $\gamma_{j}$ which will assess the importance of the relationship between non-cognitive skills and earnings.

$\ln \left(\right.$ wage $\left._{i}\right)=\beta_{0}+\beta_{1} E_{d u c_{i}}+\beta_{2} E_{d u c_{i}^{2}}+\beta_{3} \operatorname{Exper}_{i}+\beta_{4} \operatorname{Exper}_{i}^{2}+\beta_{5} \operatorname{Cogn}_{i}+\beta_{6} \operatorname{Cogn}_{i}^{2}+$ $\sum_{j=1}^{5} \gamma_{j}\left(\right.$ Non_cogn $\left._{i, j}\right)+\mathbf{z}_{i}^{\prime} \omega+\varepsilon_{i}$

A priori, we expect to find that, similarly to the literature, education, experience and cognitive ability are positively associated with wages. For the Big Five, we expect conscientiousness to be strongly positively associated with wages for all sub-populations and occupations, while returns to the other four characteristics may display a higher degree of variability.

\section{RESULTS AND DISCUSSION}

\section{OLS Estimation of Models 1-4}

Estimation of the four above models proceeds using standard ordinary least squares (OLS) estimation. The usual Huber-White robust standard error estimates are inappropriate here, due to the complexity of the survey sampling design, so standard error estimates are calculated using 1000 bootstrap replication weights, supplied by Statistics Canada. Preliminary estimates of Models 1 to 3, along with Green and Riddell's estimates for comparison purposes, are found in Table 5.

All else held constant, the results suggest that an additional year of education on average yields a $7.4 \%$ return to wages, with an additional year of work experience yielding $7.1 \%$. Returns to experience are stable across the three models, while returns to education fall by about $30 \%$ after controlling for cognitive ability, likely due to the positive correlation between cognition and education level. The square of education and experience both yield negative, statistically significant estimates, suggesting concavity in returns.

Model 2 yields some other notable results, such as members of a union earn $25.6 \%$ more on average than non-members, while those that are single earn nearly $16 \%$ less. Having a degree from outside Canada or being an immigrant is not deemed to be a significant part of wage determination. 
Model 3 also suggests that the returns to cognitive ability itself are higher than both the returns to education and experience, with a one standard deviation increase yielding, on average, $11 \%$ higher income. The interaction term with Experience is positive but small and non-significant, suggesting that returns to experience do not vary significantly across the distribution of cognitive ability.

Overall, our Model 3 estimates are in the same direction and degree of significance as those of Green and Riddell. We find, however, that our estimates are significantly smaller in magnitude, in particular for cognitive ability, which reaches only approximately $20 \%$ the magnitude of Green and Riddell's estimate.

Estimating the models by gender yields the results in Table 6. By and large, estimates seem to follow a similar pattern to the all-sample regressions and do not seem to exhibit a great deal of difference between genders. The only notable difference is for Model 3, where the returns to years of education seem to be smaller for males than females, while the opposite is true for the benefits of an additional year of experience. Statistical significance is lost on the cognitive ability indicator for both males and females, however the magnitude of the estimate for males is very similar to that of the all-sample regression in Table 5.

We now turn to our final specification of the model, including the Big Five indicators. We estimate four iterations of Model 4 with different sets of indicator variable controls. Results for the first two iterations are found in Table 7. The first iteration includes only an indicator for the province of residence of the respondent to control for province fixed effects. In the second iteration we closely follow the existing literature by also including an indicator for the broad industrial category of the respondent's occupation, to control for industry fixed effects and alleviate the confounding effect of high-ability individuals self-selecting into higher-paying industries.

TABLE 5

\section{ALL SAMPLE LOG INCOME REGRESSION RESULTS FOR MODELS 1-3}

\begin{tabular}{|c|c|c|c|c|}
\hline Regressors & Model 1 & Model 2 & Model 3 & $\begin{array}{c}\text { G\&R (2003) } \\
\text { Results }\end{array}$ \\
\hline \multirow[t]{2}{*}{ Education } & $0.108^{*}$ & $0.099^{* * *}$ & $0.074^{* * *}$ & $0.180^{* * *}$ \\
\hline & $(0.022)$ & $(0.016)$ & $(0.017)$ & $(0.037)$ \\
\hline \multirow[t]{2}{*}{$(\text { Education })^{2}$} & $-0.001^{* * *}$ & $-0.001^{* * *}$ & $-0.001^{*}$ & $-0.005^{* *}$ \\
\hline & $(0.001)$ & $(0.000)$ & $(0.000)$ & $(0.001)$ \\
\hline \multirow[t]{2}{*}{ Experience } & $0.070^{* * *}$ & $0.069^{* * *}$ & $0.071^{* * *}$ & $0.120^{* *}$ \\
\hline & $(0.009)$ & $(0.009)$ & $(0.008)$ & $(0.017)$ \\
\hline \multirow[t]{2}{*}{$(\text { Experience })^{2}$} & $-0.001^{* * *}$ & $-0.001^{* * *}$ & $-0.001^{* * *}$ & $-0.001^{* *}$ \\
\hline & $(0.000)$ & $(0.000)$ & $(0.000)$ & $(0.000)$ \\
\hline \multirow[t]{2}{*}{ Cognitive ability } & -- & -- & $0.110^{* *}$ & $0.540^{* *, \dagger}$ \\
\hline & & & $(0.056)$ & $(0.001)$ \\
\hline Cognitive ability $x$ & -- & -- & 0.003 & $0.000^{* *}$ \\
\hline Experience & & & $(0.003)$ & $(0.000)$ \\
\hline Union & -- & $\begin{array}{l}0.256^{* * *} \\
(0.067)\end{array}$ & -- & -- \\
\hline Single & -- & $\begin{array}{c}-0.155^{* * *} \\
(0.04)\end{array}$ & -- & -- \\
\hline Degree outside Canada & -- & $\begin{array}{l}-0.115 \\
(0.075)\end{array}$ & -- & -- \\
\hline Immigrant & -- & $\begin{array}{l}-0.042 \\
(0.068)\end{array}$ & -- & -- \\
\hline
\end{tabular}


Parental Education

Province Indicators

R-squared

Sample size

Weighted Obs.

\begin{tabular}{ccccc} 
No & Yes & Yes & & Yes \\
No & Yes & No & & No \\
0.252 & 0.287 & 0.281 & & 0.3 \\
\hline \multicolumn{3}{c}{3,571} & & 646 \\
& $13,859,611$ & & -- \\
\hline
\end{tabular}

$* * *: \mathrm{p} \leq 0.01,{ }^{* *}: \mathrm{p} \leq 0.05, *: \mathrm{p} \leq 0.1$

${ }^{\dagger}$ : Coefficient for a one standard deviation increase in cognitive score

Bootstrap standard errors in parentheses.

TABLE 6

LOG INCOME REGRESSION RESULTS BY GENDER FOR MODELS 1-3

\begin{tabular}{|c|c|c|c|c|c|c|}
\hline \multirow{2}{*}{ Regressors } & \multicolumn{3}{|c|}{ Males } & \multicolumn{3}{|c|}{ Females } \\
\hline & Model 1 & Model 2 & Model 3 & Model 1 & Model 2 & Model 3 \\
\hline \multirow[t]{2}{*}{ Education } & $0.128^{* * *}$ & $0.104^{* * *}$ & 0.056 & $0.131^{* * *}$ & $0.120^{* * *}$ & $0.112^{* * *}$ \\
\hline & $(0.033)$ & $(0.031)$ & $(0.038)$ & $(0.022)$ & $(0.025)$ & $(0.028)$ \\
\hline \multirow[t]{2}{*}{$(\text { Education })^{2}$} & $-0.002^{* * *}$ & $-0.002^{* *}$ & -0.001 & $-0.001^{* *}$ & $-0.001^{*}$ & -0.001 \\
\hline & $(0.001)$ & $(0.001)$ & $(0.001)$ & $(0.001)$ & $(0.001)$ & $(0.001)$ \\
\hline \multirow[t]{2}{*}{ Experience } & $0.085^{* * *}$ & $0.082^{* * *}$ & $0.085^{* * *}$ & $0.057^{* * *}$ & $0.057^{* * *}$ & $0.058^{* * *}$ \\
\hline & $(0.024)$ & $(0.024)$ & $(0.022)$ & $(0.008)$ & $(0.009)$ & $(0.008)$ \\
\hline \multirow[t]{2}{*}{$(\text { Experience })^{2}$} & $-0.001^{* *}$ & $-0.001^{* *}$ & $-0.001^{* *}$ & $0.001^{* * *}$ & $0.001^{* * *}$ & $-0.001^{* * *}$ \\
\hline & $(0.001)$ & $(0.001)$ & $(0.001)$ & $(0.000)$ & $(0.000)$ & $(0.000)$ \\
\hline \multirow[t]{2}{*}{ Cognitive ability } & -- & -- & 0.115 & -- & -- & 0.066 \\
\hline & & & $(0.103)$ & & & $(0.048)$ \\
\hline \multirow{2}{*}{$\begin{array}{l}\text { Cognitive ability } \times \\
\text { Experience }\end{array}$} & -- & -- & 0.004 & -- & -- & 0.002 \\
\hline & & & $(0.004)$ & & & $(0.002)$ \\
\hline \multirow[t]{3}{*}{ Union } & -- & $0.157^{* *}$ & -- & -- & $0.382^{* * *}$ & -- \\
\hline & & $(0.077)$ & & & $(0.068)$ & \\
\hline & & - & & & & \\
\hline \multirow[t]{2}{*}{ Single } & -- & $0.248^{* * *}$ & -- & -- & -0.065 & -- \\
\hline & & $(0.063)$ & & & $(0.052)$ & \\
\hline \multirow[t]{2}{*}{ Degree outside Canada } & -- & -0.166 & -- & -- & -0.061 & -- \\
\hline & & $(0.111)$ & & & $(0.100)$ & \\
\hline \multirow[t]{2}{*}{ Immigrant } & -- & -0.139 & -- & -- & 0.063 & -- \\
\hline & & $(0.108)$ & & & $(0.084)$ & \\
\hline Parental Education & No & Yes & Yes & No & Yes & Yes \\
\hline Province Dummies & No & Yes & No & No & Yes & No \\
\hline R-squared & 0.258 & 0.297 & 0.294 & 0.258 & 0.302 & 0.268 \\
\hline Sample size & & 1,648 & & & 1,923 & \\
\hline Weighted Obs. & & $6,967,100$ & & & $6,892,511$ & \\
\hline
\end{tabular}

${ }^{* * *}: \mathrm{p} \leq 0.01,{ }^{* *}: \mathrm{p} \leq 0.05, * \mathrm{p} \leq 0.1$

Bootstrap standard errors in parentheses. 
TABLE 7

TWO SPECIFICATIONS OF MODEL 4

\begin{tabular}{|c|c|c|c|c|c|c|}
\hline \multirow{2}{*}{ Regressors } & \multicolumn{2}{|c|}{ Full Sample } & \multicolumn{2}{|c|}{ Males } & \multicolumn{2}{|c|}{ Females } \\
\hline & (1) & (2) & $(1)$ & $(2)$ & (1) & (2) \\
\hline Education & $\begin{array}{l}0.070^{* * *} \\
(0.018)\end{array}$ & $\begin{array}{l}0.069^{* * *} \\
(0.017)\end{array}$ & $\begin{array}{c}0.068^{*} \\
(0.037)\end{array}$ & $\begin{array}{c}0.066^{*} \\
(0.035)\end{array}$ & $\begin{array}{l}0.100^{* * *} \\
(0.024)\end{array}$ & $\begin{array}{l}0.096^{* * *} \\
(0.021)\end{array}$ \\
\hline$(\text { Education })^{2}$ & $\begin{array}{l}-0.001^{*} \\
(0.000)\end{array}$ & $\begin{array}{l}-0.001^{*} \\
(0.000)\end{array}$ & $\begin{array}{l}-0.001 \\
(0.001)\end{array}$ & $\begin{array}{l}-0.001 \\
(0.001)\end{array}$ & $\begin{array}{l}-0.001 \\
(0.001)\end{array}$ & $\begin{array}{l}-0.001^{*} \\
(0.001)\end{array}$ \\
\hline Experience & $\begin{array}{l}0.065^{* * *} \\
(0.008)\end{array}$ & $\begin{array}{l}0.058^{* * *} \\
(0.008)\end{array}$ & $\begin{array}{l}0.077^{* * *} \\
(0.023)\end{array}$ & $\begin{array}{l}0.068^{* * *} \\
(0.021)\end{array}$ & $\begin{array}{l}0.055^{* * *} \\
(0.008)\end{array}$ & $\begin{array}{l}0.051^{* * *} \\
(0.008)\end{array}$ \\
\hline$(\text { Experience })^{2}$ & $\begin{array}{l}-0.001^{* * *} \\
(0.000)\end{array}$ & $\begin{array}{l}-0.001^{* * *} \\
(0.000)\end{array}$ & $\begin{array}{l}-0.001^{* *} \\
(0.001)\end{array}$ & $\begin{array}{l}-0.001^{*} \\
(0.001)\end{array}$ & $\begin{array}{l}-0.001^{* * *} \\
(0.000)\end{array}$ & $\begin{array}{l}-0.001^{* * *} \\
(0.000)\end{array}$ \\
\hline Cognitive ability & $\begin{array}{l}0.161^{* * *} \\
(0.029)\end{array}$ & $\begin{array}{l}0.137^{* * *} \\
(0.029)\end{array}$ & $\begin{array}{l}0.171^{* * *} \\
(0.049)\end{array}$ & $\begin{array}{l}0.139^{* * *} \\
(0.048)\end{array}$ & $\begin{array}{l}0.113^{* * *} \\
(0.031)\end{array}$ & $\begin{array}{l}0.102^{* * *} \\
(0.031)\end{array}$ \\
\hline$(\text { Cognitive ability })^{2}$ & $\begin{array}{l}0.045^{* * *} \\
(0.018)\end{array}$ & $\begin{array}{l}0.044^{* * *} \\
(0.017)\end{array}$ & $\begin{array}{c}0.029 \\
(-0.03)\end{array}$ & $\begin{array}{c}0.028 \\
(0.029)\end{array}$ & $\begin{array}{l}0.048^{* * *} \\
(0.018)\end{array}$ & $\begin{array}{c}0.046 \\
(0.018)\end{array}$ \\
\hline $\begin{array}{l}\text { Openness to } \\
\text { experience }\end{array}$ & $\begin{array}{l}-0.003 \\
(0.021)\end{array}$ & $\begin{array}{c}0.001 \\
(-0.02)\end{array}$ & $\begin{array}{l}-0.019 \\
(0.034)\end{array}$ & $\begin{array}{l}-0.009 \\
(0.031)\end{array}$ & $\begin{array}{l}-0.020 \\
(0.025)\end{array}$ & $\begin{array}{l}-0.012 \\
(0.025)\end{array}$ \\
\hline Conscientiousness & $\begin{array}{l}0.073^{* * *} \\
(0.024)\end{array}$ & $\begin{array}{l}0.072^{* * *} \\
(0.023)\end{array}$ & $\begin{array}{l}0.074^{* *} \\
(0.031)\end{array}$ & $\begin{array}{l}0.067^{* *} \\
(0.031)\end{array}$ & $\begin{array}{l}0.097^{* * *} \\
(0.029)\end{array}$ & $\begin{array}{c}0.096 \\
(0.029)\end{array}$ \\
\hline Extraversion & $\begin{array}{l}-0.045^{*} \\
(0.023)\end{array}$ & $\begin{array}{l}-0.034^{*} \\
(-0.020)\end{array}$ & $\begin{array}{l}-0.038 \\
(0.036)\end{array}$ & $\begin{array}{l}-0.022 \\
(0.029)\end{array}$ & $\begin{array}{l}-0.007 \\
(0.024)\end{array}$ & $\begin{array}{l}-0.011 \\
(0.024)\end{array}$ \\
\hline Agreeableness & $\begin{array}{l}-0.065^{* *} \\
(0.028)\end{array}$ & $\begin{array}{l}-0.048^{*} \\
(0.027)\end{array}$ & $\begin{array}{l}-0.016 \\
(0.039)\end{array}$ & $\begin{array}{l}-0.012 \\
(0.035)\end{array}$ & $\begin{array}{l}-0.087^{* * *} \\
(0.028)\end{array}$ & $\begin{array}{l}-0.074 \\
(0.029)\end{array}$ \\
\hline Neuroticism & $\begin{array}{c}-0.060^{* * *} \\
(0.018)\end{array}$ & $\begin{array}{l}-0.036^{*} \\
(0.019)\end{array}$ & $\begin{array}{l}-0.050^{*} \\
(0.029)\end{array}$ & $\begin{array}{l}-0.037 \\
(0.027)\end{array}$ & $\begin{array}{l}-0.007 \\
(0.022)\end{array}$ & $\begin{array}{c}0.001 \\
(0.022)\end{array}$ \\
\hline Province dummies & Yes & Yes & Yes & Yes & Yes & Yes \\
\hline Industry dummies ${ }^{\dagger}$ & No & Yes & No & Yes & No & Yes \\
\hline R-squared & 0.3125 & 0.370 & 0.313 & 0.389 & 0.322 & 0.354 \\
\hline Sample size & \multicolumn{2}{|c|}{3,571} & \multicolumn{2}{|c|}{1,648} & \multicolumn{2}{|c|}{1,923} \\
\hline Weighted Obs. & \multicolumn{2}{|c|}{$13,859,611$} & \multicolumn{2}{|c|}{$6,967,100$} & \multicolumn{2}{|c|}{$6,892,511$} \\
\hline
\end{tabular}

Across both iterations and genders, the inclusion of non-cognitive skills slightly reduces the magnitude of the years of education and experience estimates with respect to Model 3, suggesting that some of the effect of education and experience on wages can be explained through the non-cognitive skills channel. In this specification, for the full sample an additional year of experience has a positive and significant effect on the order of $5.8 \%-6.5 \%$ while cognitive ability is associated with an $13.7 \%-16.1 \%$ return for a one standard deviation increase. 
Of the Big Five, conscientiousness is the only trait that is significant at all levels, across both specifications and genders. In line with expectations and all of the existing literature, conscientiousness has a relatively large, positive estimated coefficient, suggesting that a one standard deviation increase in conscientiousness is associated with $7.2 \%$ higher wages. Also in line with the literature, neuroticism is estimated to have a negative effect, suggesting that a one standard deviation increase is associated with $3.6 \%$ lower wages. These two results indicate that, on average, the labour market rewards dutifulness, competence and discipline while penalising lack of self-confidence, anxiety and irritability, on average, across all industries.

Agreeableness and extraversion, however, both have negative estimated returns, at $-4.8 \%$ and $-3.4 \%$, respectively, holding constant the education and experience level of the individual. For agreeableness, the results, though only weakly statistically significant, suggest that individuals who are more self-centered and aggressive tend to enjoy higher wages, a result which is echoed by Nyhus and Pons (2005), Mueller and Plug (2006) and Heineck and Anger (2010).

Estimating the model by gender yields results that suggest that agreeableness and conscientiousness are the only two variables in the model which exhibit notable differences between males and females, both being larger in magnitude for females than for males. In particular, while males are seemingly unaffected by their level of agreeability, females can expect a $7.4 \%-8.7 \%$ income penalty, suggesting that the negative estimated effect in the full sample is driven mostly by females. Likewise, while men can expect to earn approximately $6.7 \%-7.4 \%$ higher wages for a one-standard deviation increase in conscientiousness, the corresponding return for females is closer to $10 \%$, results that are matched, at least in direction, by Nyhus and Pons (2005).

The results discussed up until this point have controlled only for the broad industrial category the respondent is employed in. The two final specifications of Model 4 instead include more granular indicators of occupational characteristics to offer a further check against unwanted variation in income that is due to within-occupation differences in skill and task type. Results are found in Table 8. Including occupational effects yields very significant and positive estimates for the returns to working in highskilled (level A) and analytic occupations, on the order of $41.6 \%$ and $88.4 \%$ for non-routine analytic and management occupations respectively. The occupational characteristics also have the effect of reducing the impact of an additional year of education to $3.8 \%-5.7 \%$, an additional year of experience to $5.3 \%$ $5.5 \%$ and cognitive ability to $8.8 \%-11 \%$, though all still remain highly positive and statistically significant. In terms of the Big Five characteristics, accounting for occupational effects slightly reduces the magnitude of each of the estimated parameters as well, however, even within an industry and a given type of occupation, the wage returns to non-cognitive skills discussed above continue to hold true. A one standard deviation increase in conscientiousness is associated with a $6.2 \%-7.4 \%$ wage premium, while agreeableness is associated with a $4.4 \%-4.8 \%$ wage penalty. Neuroticism has an estimated $4 \%$ wage penalty but is only statistically significant in the skill specification, and the return to extraversion is reduced to the point of non-significance by the occupation type indicators. The same gender disparities identified above, where agreeableness and conscientiousness have a higher magnitude, on the order of 3 and 2 percentage points respectively, for females than for males, continues to persist. 
TABLE 8

MODEL 4 - INCLUDING OCCUPATION EFFECTS

\begin{tabular}{|c|c|c|c|c|c|c|}
\hline \multirow{2}{*}{ Regressors } & \multicolumn{2}{|c|}{ Full Sample } & \multicolumn{2}{|c|}{ Males } & \multicolumn{2}{|c|}{ Females } \\
\hline & $\mathrm{NOC}^{\dagger}$ & Task $^{\ddagger}$ & $\mathrm{NOC}^{\dagger}$ & Task $^{*}$ & $\mathrm{NOC}^{\dagger}$ & Task $^{*}$ \\
\hline \multirow[t]{2}{*}{ Education } & $0.038^{* *}$ & $0.057^{* * *}$ & 0.028 & 0.051 & $0.054^{* *}$ & $0.076^{* * *}$ \\
\hline & $(0.016)$ & $(0.016)$ & $(0.034)$ & $(0.035)$ & $(0.024)$ & $(0.023)$ \\
\hline \multirow[t]{2}{*}{ Experience } & $0.053^{* * *}$ & $0.055^{* * *}$ & $0.062^{* * *}$ & $0.065^{* * *}$ & $0.047^{* * *}$ & $0.049^{* * *}$ \\
\hline & $(0.008)$ & $(0.008)$ & $(-0.020)$ & $(-0.020)$ & $(0.008)$ & $(0.008)$ \\
\hline \multirow[t]{2}{*}{ Cognitive ability } & $0.088^{* * *}$ & $0.110^{* * *}$ & $0.100^{* *}$ & $0.105^{* *}$ & $0.054^{*}$ & $0.074^{* *}$ \\
\hline & $(0.027)$ & $(0.028)$ & $(0.045)$ & $(0.046)$ & $(-0.030)$ & $(0.032)$ \\
\hline Openness to & 0.005 & -0.004 & -0.005 & -0.012 & -0.004 & -0.013 \\
\hline Experience & $(0.019)$ & $(0.019)$ & $(-0.03)$ & $(-0.03)$ & $(0.023)$ & $(0.024)$ \\
\hline \multirow[t]{2}{*}{ Conscientiousness } & $0.062^{* * *}$ & $0.074^{* * *}$ & $0.057^{*}$ & $0.067^{* *}$ & $0.081^{* * *}$ & $0.092^{* * *}$ \\
\hline & $(0.024)$ & $(0.022)$ & $(-0.030)$ & $(-0.030)$ & $(0.029)$ & $(0.027)$ \\
\hline \multirow[t]{2}{*}{ Extraversion } & -0.028 & -0.027 & -0.022 & -0.005 & -0.010 & -0.013 \\
\hline & $(0.019)$ & $(-0.020)$ & $(0.029)$ & $(0.027)$ & $(0.022)$ & $(0.023)$ \\
\hline \multirow[t]{2}{*}{ Agreeableness } & $-0.048^{* *}$ & $-0.044^{*}$ & -0.011 & -0.014 & $-0.073^{* * *}$ & $-0.070^{* *}$ \\
\hline & $(0.023)$ & $(0.027)$ & $(0.031)$ & $(0.033)$ & $(0.026)$ & $(0.028)$ \\
\hline \multirow[t]{2}{*}{ Neuroticism } & -0.026 & $-0.040^{* *}$ & -0.026 & $-0.048^{*}$ & 0.010 & 0.001 \\
\hline & $(0.019)$ & $(0.018)$ & $(0.025)$ & $(0.027)$ & $(0.022)$ & $(0.022)$ \\
\hline \multirow[t]{2}{*}{ Management } & $0.884^{* * *}$ & -- & $0.822^{* * *}$ & -- & $0.860^{* * *}$ & -- \\
\hline & $(0.058)$ & & $(0.092)$ & & $(0.077)$ & \\
\hline \multirow[t]{2}{*}{ Skill level A } & $0.537^{* * *}$ & -- & $0.401^{* * *}$ & -- & $0.595^{* * *}$ & -- \\
\hline & $(0.062)$ & & $(0.111)$ & & $(0.067)$ & \\
\hline \multirow[t]{2}{*}{ Skill level B } & $0.379^{* * *}$ & -- & $0.371^{* * * *}$ & -- & $0.325^{* * *}$ & -- \\
\hline & $(0.042)$ & & $(0.066)$ & & $(0.057)$ & \\
\hline Non-routine & -- & $0.416^{* * *}$ & -- & $0.372^{* * *}$ & -- & $0.524^{* * *}$ \\
\hline analytic & & $(0.062)$ & & $(0.089)$ & & $(0.088)$ \\
\hline Routine & -- & $0.254^{* * *}$ & -- & $0.296^{* * *}$ & -- & $0.294^{* * *}$ \\
\hline cognitive & & $(0.055)$ & & $(0.080)$ & & $(0.069)$ \\
\hline Non-routine & -- & $0.272^{* * *}$ & -- & $0.280^{* * *}$ & -- & 0.051 \\
\hline manual & & $(0.055)$ & & $(0.071)$ & & $(0.094)$ \\
\hline Non-routine & -- & 0.011 & -- & -0.165 & -- & $0.176^{* * *}$ \\
\hline interactive & & $(0.060)$ & & $(0.115)$ & & $(0.066)$ \\
\hline Province dummies & Yes & Yes & Yes & Yes & Yes & Yes \\
\hline Industry dummies & Yes & Yes & Yes & Yes & Yes & Yes \\
\hline R-squared & 0.423 & 0.389 & 0.430 & 0.415 & 0.417 & 0.377 \\
\hline Sample size & \multicolumn{2}{|c|}{3,571} & \multicolumn{2}{|c|}{1,648} & \multicolumn{2}{|c|}{1923} \\
\hline Weighted Obs. & \multicolumn{2}{|c|}{$13,859,611$} & \multicolumn{2}{|c|}{$6,967,100$} & \multicolumn{2}{|c|}{$6,892,511$} \\
\hline
\end{tabular}




\section{CONCLUSION}

In addressing the question of whether non-cognitive skills are important to the income of Canadians, our preceding results suggest that the returns to these endowments depend upon the skill in question and the gender of the individual but are largely in line with what already exists in the literature. Of the 'Big Five' characteristics, Conscientiousness, being the only trait that is directly associated with commitment to work-related tasks, is, unsurprisingly, the only factor that is consistently associated with positive and significant returns, on the order of about $6.2 \%-7.4 \%$ for the full sample of the final two model specifications. Extraversion, agreeableness and neuroticism are associated with negative returns ranging between $-2.6 \%--4.8 \%$ for the full sample, and the latter two exhibit differences by gender, with estimates for females appearing to be greater in magnitude than for males. Openness to Experience is consistently estimated to be small and non-significant. Cognitive ability, on the other hand, appears to be a much more highly rewarded factor, with estimates between about 13 - 16\%, depending on specification. Overall then, the results suggest that non-cognitive skills do play a role in wage determination but this role is relatively modest in comparison with that of cognitive ability, is highest for traits closely associated with workplace competence, and displays heterogeneity by gender. For the 'Big Five' characteristics, our estimates seem to be of the same direction and order of magnitude as existing studies, and also follow similar patterns of differences by gender. Our results help to fill an important gap in evidence for Canadian workers and also solidify support behind the idea that personality traits can have real, economic effects. More generally, our estimates also support the idea that wages and income are determined by more than just education and experience, and thus that non-cognitive skills are important to monitor in assessments of the skill level of the workforce.

\section{ENDNOTES}

1. As a notational sidenote, the literature suggests a difference between an ability and a skill, in that the term 'ability' may imply a fixed, potentially genetic, endowment of a characteristic and a skill may improve over time. However, in keeping with convention in the economics literature, we use the term 'non-cognitive skills' in this study, with the assumption that personality traits are relatively immutable over time. For more discussion on this topic, see Thiel and Thomsen (2013).

2. Notable exceptions to the sample include those living in the three Territories and Indigenous individuals living on a reserve. Statistics Canada estimates that only approximately $2 \%$ of the entire Canadian population is excluded from the sample.

http://www23.statcan.gc.ca/imdb/p2SV.pl?Function=getSurvey $\ \&$ SDDS=5144

3. There is a gap of two years in the time between when an individual's cognitive abilities were measured with PIAAC in 2012 and when their non-cognitive skills were measured through LISA in 2014. Facets of the literature indicate that non-cognitive skills exhibit rigidity over time, so we reasonably assume that there is no degradation or appreciation over this time period

4. This could prove to be problematic if selection into the PIAAC sample or attrition between the LISA waves are correlated with the variables we are interested in. We investigated this question in depth and found that, while individuals below the $40^{\text {th }}$ percentile of income were slightly less likely to be included in the sample, the overall effect is very small and will be assumed to be negligible.

5. Available at the following URL, under 'Key Indicators' by selecting 'Average Age': https://www12.statcan.gc.ca/census-recensement/index-eng.cfm

6. We omit the Problem Solving in a Technology-Rich Environment (PS-TRE) questions due to a reduction in sample size and questions of non-random selection.

7. The formula used to compute corrected standard errors is $\widehat{\operatorname{Var}}\left(P V_{s}\right)=\left(1+\frac{1}{K}\right)\left[\frac{1}{K-1} \sum_{i}\left(P V_{s, i}-\overline{P V}_{s}\right)^{2}\right]+$ $\frac{1}{K} \sum_{i} \widehat{\operatorname{Var}}\left(P V_{s, i}\right)$

8. Test statistic: $\hat{t}=\frac{279.73-266.84}{\sqrt{1.83^{2}+1.68^{2}}}=5.19$

9. There is also of course the question of whether or not individuals accurately respond to personality questions, or purposefully choose a more socially desirable survey response. Unfortunately, we have no robust method to test these hypotheses. However, John and Srivastava (1999), Gosling, Rentfrow and 
Swann (2003) and others demonstrate that the self-reported five-item inventory of the Big Five personality dimensions, in particular, is able to accurately identify the desired personality traits, gives reliable results over time (based on a test-retest experiment) and corresponds well with peer reports. Knowles and Condon (1999) further suggest that the use of multiple survey questions can help to clarify the trait for the respondent, and the use of a physical survey medium can reduce pressure on the respondent and thus ward against bias. Based on this, we assume that any potential bias is only a minor concern.

\section{REFERENCES}

Allport, G.W., \& Odbert, H.S. (1936). Trait-Names: A Psycho-Lexical Study. Psychological Monographs, 47(1), i-171.

Almlund, M., Duckworth, A., \& Kautz, T. (2011). Personality Psychology and Economics. In Hanushek, E., Machin, S., and Woessman, L. (Eds.) Handbook of the Economics of Education. (pp. 1-181). Amsterdam, Elsevier.

Autor, D. H., Levy F., \& Murnane, R.J. (2003). The Skill Content of Recent Technological Change: An Empirical Exploration. Quarterly Journal of Economics, 118(4), 1279-1333.

Barrett, G.F. (2012). The Return to Cognitive Skills in the Australian Labour Market. Economic Record, $88,1-17$.

Barrick, M., \& Mount, M. (1991). The Big Five Personality Dimensions and Job Performance: A MetaAnalysis. Personnel Psychology, 44(1), 1-26.

Borghans, L., Duckworth, A.L., Heckman, J.J., \& ter Weel, B. (2008). The Economics and Psychology of Personality Traits. Journal of Human Resources, 43(4), 972-1059.

Borghans, L., ter Weel, B., \& Weinberg, B. (2014). People People: Social Capital and the Labor-Market Outcomes of Underrepresented Groups. Industrial and Labor Relations Review, 67(2), 287-334.

Cawley, J., Heckman J.J., \& Vytlacil, E. (2001). Three Observations on Wages and Measured Cognitive Ability. Labour Economics, 8(4), 419-442.

Cobb-Clark, D. A., \& Schurer, S. (2012). The Stability of Big-Five Personality Traits. Economics Letters, 115(1), 11-15.

Cobb-Clark, D. A., \& Tan M. (2011). Noncognitive Skills, Occupational Attainment, and Relative Wages. Labour Economics, 18(1), 1-13.

Costa, P.T., \& McCrae, R.R. (1985) The NEO Personality Inventory Manual. Psychological Assessment Resources, Odessa, FL.

Cunha, F., \& Heckman, J. J. (2007). The Technology of Skill Formation. American Economic Review, 97(2), 31-47.

Cunha, F., Heckman J.J., \& Schennach, S.M. (2010). Estimating the Technology of Cognitive and Noncognitive Skill Formation. Econometrica, 78(3), 883-931.

Cunha, F., Heckman, J. J., Lochner, L., \& Masterov, D. V. (2006). Chapter 12 Interpreting the Evidence on Life Cycle Skill Formation. In E. Hanushek and F. Welch (Eds.), Handbook of the Economics of Education (Volume 1, pp. 697-812).

Deming, D.J. (2017). The Growing Importance of Social Skills in the Labor Market. Quarterly Journal of Economics, 132(4), 1593-1640.

Edin, P-A, Fredriksson, P., Nybom M., \& Öckert B. (2017). The Rising Return to Non-cognitive Skill. Working paper, Department of Economics, Uppsala University.

Fletcher, J. M. (2013). The effects of personality traits on adult labor market outcomes: Evidence from siblings. Journal of Economic Behavior Organization, 89, 122-135.

Green, D., \& Riddell, W.C. (2003). Literacy and earnings: an investigation of the interaction of cognitive and unobserved skills in earnings generation. Labour Economics, 10(2), 165-184.

Goldberg, L.R. (1971). A historical survey of personality scales and inventories. In P. McReynolds (Ed.), Advances in Psychological Assessment (Volume 2, pp. 293-336).

Goldberg, L.R. (1998). What is Beyond the Big Five? Journal of Personality, 66(4), 495-524. 
Gosling, S.D., Rentfrow, P.J., \& Swann, W.B. (2003). A Very Brief Measure of the Big-Five Personality Domains. Journal of Research in Personality, 37(6), 504-528.

Hanushek, E. A., Schwerdt G., Wiederhold, S., \& Woessmann, L. (2015). Returns to skills around the world: Evidence from PIAAC. European Economic Review, 73(C), 103-130.

Heckman, J. J., \& Rubinstein, Y. (2001). The Importance of Noncognitive Skills: Lessons from the GED Testing Program. American Economic Review, 91(2), 145-149.

Heckman, J.J., Stixrud J., \& Urzua, S. (2006). The Effects of Cognitive and Noncognitive Abilities on Labor Market Outcomes and Social Behavior. Journal of Labor Economics, 24(3), 411-482.

Heineck, G., \& Anger S. (2010). The Returns to Cognitive Abilities and Personality Traits in Germany. Labour Economics, 17, 535-546.

John, O. P., \& Srivastava, S. (1999). The Big Five Trait Taxonomy: History, Measurement, and Theoretical Perspectives. in L. A. Pervin and O. P. John (Eds.), Handbook of Personality: Theory and Research (pp. 102-138). New York, NY: Guilford Press.

Judge, T. A., Higgins, C.A., Thoresen, C.J., Barrick, \& Murray R. (1999). The Big Five Personality Traits, General Mental Ability, and Career Success Across the Life Span. Personnel Psychology, $52,621-652$.

Kautz, T., Heckman, J.J., Diris, R., ter Weel, B., \& Borghans, L. (2014). Fostering and Measuring Skills: Improving Cognitive and Non-Cognitive Skills to Promote Lifetime Success. OECD Education Working Papers 110, OECD Publishing.

Knowles, E.S., \& Condon, C.A. (1999). Why People Say "Yes": A Dual-Process Theory of Acquiescence. Journal of Personality and Social Psychology, 77(2), 379-386.

Kolenikov, S., \& Angeles, G. (2004). The Use of Discrete Data in PCA: Theory, Simulations, and Applications to Socioeconomic Indices. MEASURE Evaluation Working Paper Series. Retrieved from MEASURE Evaluation website: https://www.measureevaluation.org/resources/publications/wp-04-85

Lang, F., John, D., Lüdtke, O., Schupp, J., \& Wagner G.G. (2011). Short Assessment of the Big Five: Robust Across Survey Methods Except Telephone Interviewing. Behavioural Research Methods, 43(2), 548-567.

Lindqvist, E., \& Vestman, R. (2011). The Labor Market Returns to Cognitive and Noncognitive Ability: Evidence from the Swedish Enlistment. American Economic Journal: Applied Economics, 3(1), 101-28.

Lundberg, S. (2017). Non-Cognitive Skills as Human Capital, in C.R. Hulten. and V. A. Ramey (Eds.), Education, Skills, and Technical Change: Implications for Future US GDP Growth, Chicago: University of Chicago Press.

Maczulskij, T., \& Viinikainen, J. (2018). Is personality related to permanent earnings? Evidence Using a Twin Design. Journal of Economic Psychology, 64, 116-129.

McCrae, R.R., and John, O.P. (1992) An Introduction to the Five-Factor Model and its Applications. Journal of Personality, 60, 175-215.

Mischel, W. (1973). Toward a cognitive social learning reconceptualization of personality. Psychological Review, 80(4), 252-283.

Mueller, G., \& Plug, E. (2006). Estimating the Effects of Personality on Male and Female Earnings. Industrial and Labor Relations Review, 60(1), 3-22.

Nyhus, E. K., \& Pons, E. (2005). The Effects of Personality on Earnings. Journal of Economic Psychology, 26(3), 363-384.

Nyhus, E. K., \& Pons, E. (2012). Personality and the Gender Wage Gap. Applied Economics, 44(1), 105118.

Proto, E., \& Rustichini, A. (2015). Life satisfaction, income and personality. Journal of Economic Psychology, 48, 17-32.

Tett, R., Jackson, D., \& Rothstein, M. (1991). Personality Measures as Predictors of Job Performance: A Meta-Analytic Review. Personnel Psychology, 44(4), 703-742. 
Thiel, H., \&Thomsen, S. (2013). Noncognitive Skills in Economics: Models, Measurement, and Empirical Evidence. Research in Economics, 67(2), 189-214.

Todd, P. E., \& Zhang, W. (2017). A Dynamic Model of Personality, Schooling, and Occupational Choice. Cambridge Working Papers in Economics 1912, University of Cambridge.

Van Eijck, K., \& de Graaf, P.M. (2004). The Big Five at School: The Impact of Personality on Educational Attainments. The Netherlands'Journal of Social Sciences, 41(1), 24-42.

Viinikainen, J., Kokko, K., Pulkkinen, L., \& Pehkonen, J. (2010). Personality and Labour Market Income: Evidence from Longitudinal Data. Labour, 24(2), 201-220.

von Davier, M., Gonzalez, \& Mislevy. (2009). What are plausible values and why are they useful? IERI Monograph Series, 2, 9-36.

Weinberger, C.J. (2014). The Increasing Complementarity between Cognitive and Social Skills. Review of Economics and Statistics, 96(5), 849-861. 


\section{APPENDIX A - THE 'BIG FIVE' INVENTORY}

Research attempting to determine how to define personality goes back to early efforts in the 1930s that were based on finding thousands of the most important words describing personality traits in the English language. In the decades that followed, this list was narrowed down to a hierarchy of characteristics which are theorised to be the related to biological factors which determine the immutable features of personality. The Big Five Inventory (BFI) has emerged from this effort as the primary taxonomy to both define and measure personality. The Big Five traits consist of those traits at the very top of the hierarchy, which are made up of combinations of other factors. The second-highest level of the Big Five Inventory hierarchy is more granular, consisting of 30 facets, or personality markers, outlined in Table 9.

For our non-cognitive skill indicators, we use responses to a series of 15 questions asked in the LISA survey, derived directly from the BFI. Which questions are tied to which personality traits, and the specific questions themselves, are denoted in Table 10. An advantage of using the BFI to measure noncognitive skills is our ability to depend on the reliability of the inventory at measuring personality traits. John and Srivastava (1999) suggest that the BFI performs well in test-retest analysis, and that BFI self ratings are typically very strongly correlated with peer ratings, indicating that self-reporting bias is minimal. Lang et al. (2011) also offer evidence that even a limited number of survey questions is sufficient to identify each personality trait, particularly when the survey is administered electronically or on paper. 
TABLE 9

THE 'BIG FIVE' PERSONALITY TRAITS AND FACETS

\begin{tabular}{|c|c|c|c|}
\hline Dimension & & Facets & \\
\hline Openness vs. Closedness to Experience & $\begin{array}{c}\text { Ideas } \\
\text { (curious) } \\
\text { Actions } \\
\text { (wide interests) }\end{array}$ & $\begin{array}{c}\text { Fantasy } \\
\text { (imaginative) } \\
\text { Feelings } \\
\text { (excitable) }\end{array}$ & $\begin{array}{c}\text { Aesthetics } \\
\text { (artistic) } \\
\text { Values } \\
\text { (unconventional) }\end{array}$ \\
\hline $\begin{array}{l}\text { Conscientiousness vs. Lack of } \\
\text { direction }\end{array}$ & $\begin{array}{l}\text { Competence } \\
\text { (efficient) } \\
\text { Achievement } \\
\text { (thorough) }\end{array}$ & $\begin{array}{c}\text { Order } \\
\text { (organised) } \\
\text { Self-discipline } \\
\text { (not lazy) }\end{array}$ & $\begin{array}{c}\text { Dutifulness } \\
\text { (not careless) } \\
\text { Deliberation } \\
\text { (not impulsive) }\end{array}$ \\
\hline Extraversion vs. Introversion & $\begin{array}{l}\text { Gregariousness } \\
\text { (sociable) } \\
\text { Excitement- } \\
\text { seeking } \\
\text { (adventurous) }\end{array}$ & $\begin{array}{l}\text { Assertiveness } \\
\text { (forceful) } \\
\text { Positive } \\
\text { (enthusiatic) }\end{array}$ & $\begin{array}{l}\text { Activity } \\
\text { (energetic) } \\
\text { Warmth } \\
\text { (outgoing) }\end{array}$ \\
\hline Agreeableness vs. Antagonism & $\begin{array}{c}\text { Trust } \\
\text { (forgiving) } \\
\text { Compliance } \\
\text { (not stubborn) }\end{array}$ & $\begin{array}{l}\text { Straightforwardnes } \\
\text { S } \\
\text { (not demanding) } \\
\text { Modesty } \\
\text { (not show-off) }\end{array}$ & $\begin{array}{c}\text { Altruism } \\
\text { (warm) } \\
\text { Tenderness } \\
\text { (sympathetic) }\end{array}$ \\
\hline Neuroticism vs. Emotional stability & $\begin{array}{c}\begin{array}{c}\text { Anxiety } \\
\text { (tense) }\end{array} \\
\text { Self-consciousness } \\
\text { (shy) }\end{array}$ & $\begin{array}{l}\text { Angry hostility } \\
\text { (irritable) } \\
\text { Impulsiveness } \\
\text { (moody) }\end{array}$ & $\begin{array}{c}\text { Depression } \\
\text { (not contended) } \\
\text { Vulnerability } \\
\text { (not self- } \\
\text { confident) }\end{array}$ \\
\hline
\end{tabular}

Source: John and Srivastava (1999) 


\section{TABLE 10}

\section{LISA BIG FIVE INVENTORY QUESTIONS}

\begin{tabular}{|c|c|c|c|}
\hline Personality Trait & BFI Question & Question Text & Facet \\
\hline \multirow[t]{3}{*}{$\begin{array}{l}\text { Openness to } \\
\text { Experience }\end{array}$} & 20 & $\begin{array}{c}\text { I see myself as someone who is original, } \\
\text { comes up with new ideas. }\end{array}$ & Ideas (curious) \\
\hline & 45 & $\begin{array}{c}\text { I see myself as someone who values artistic, } \\
\text { aesthetic experiences }\end{array}$ & $\begin{array}{l}\text { Aesthetics } \\
\text { (artistic) }\end{array}$ \\
\hline & 70 & $\begin{array}{c}\text { I see myself as someone who has an active } \\
\text { imagination }\end{array}$ & $\begin{array}{c}\text { Fantasy } \\
\text { (imaginative) }\end{array}$ \\
\hline \multirow[t]{3}{*}{ Conscientiousness } & 5 & $\begin{array}{l}\text { I see myself as someone who does a thorough } \\
\text { job }\end{array}$ & $\begin{array}{l}\text { Dutifulness (not } \\
\text { careless) }\end{array}$ \\
\hline & 30 & I see myself as someone who tends to be lazy & $\begin{array}{l}\text { Self-discipline } \\
\quad \text { (not lazy) }\end{array}$ \\
\hline & 55 & $\begin{array}{c}\text { I see myself as someone who does things } \\
\text { efficiently }\end{array}$ & $\begin{array}{l}\text { Competence } \\
\text { (efficient) }\end{array}$ \\
\hline \multirow[t]{3}{*}{ Extraversion } & 10 & I see myself as someone who is talkative & $\begin{array}{l}\text { Gregariousness } \\
\quad \text { (sociable) }\end{array}$ \\
\hline & 35 & $\begin{array}{c}\text { I see myself as someone who is outgoing and } \\
\text { sociable }\end{array}$ & $\begin{array}{l}\text { Warmth } \\
\text { (outgoing) }\end{array}$ \\
\hline & 60 & I see myself as someone who is reserved & $\begin{array}{l}\text { Assertiveness } \\
\text { (forcefulness) }\end{array}$ \\
\hline \multirow[t]{3}{*}{ Agreeableness } & 1 & $\begin{array}{c}\text { I see myself as someone who is sometimes } \\
\text { rude to others }{ }^{\dagger}\end{array}$ & $\begin{array}{l}\text { Tenderness } \\
\text { (sympathetic) }\end{array}$ \\
\hline & 25 & $\begin{array}{c}\text { I see myself as someone who has a forgiving } \\
\text { nature }\end{array}$ & Trust (forgiveness) \\
\hline & 50 & $\begin{array}{c}\text { I see myself as someone who is considerate } \\
\text { and kind to almost everyone }\end{array}$ & $\begin{array}{l}\text { Tenderness } \\
\text { (sympathetic) }\end{array}$ \\
\hline \multirow[t]{3}{*}{ Neuroticism } & 15 & I see myself as someone who worries a lot & Anxiety (tense) \\
\hline & 40 & $\begin{array}{l}\text { I see myself as someone who gets nervous } \\
\text { easily }\end{array}$ & $\begin{array}{l}\text { Impulsiveness } \\
\quad(\text { moody })\end{array}$ \\
\hline & 65 & $\begin{array}{c}\text { I see myself as someone who is relaxed, who } \\
\text { handles stress well }\end{array}$ & Anxiety (tense) \\
\hline
\end{tabular}

${ }^{\dagger}$ : Inverted Scale

Source: Lang et al. (2011), Statistics Canada (2014) 